\title{
Poliovirus Mutant That Does Not Selectively Inhibit Host Cell Protein Synthesis
}

\author{
HARRIS D. BERNSTEIN,${ }^{1}$ NAHUM SONENBERG,${ }^{2}$ AND DAVID BALTIMORE ${ }^{1 *}$ \\ Whitehead Institute for Biomedical Research, Cambridge, Massachusetts 02142, and Department of Biology, \\ Massachusetts Institute of Technology, Cambridge, Massachusetts 02139. ${ }^{1}$ and Department of Biochemistry, McGill \\ University, Montreal, Quebec, Canada H3G IY6²
}

Received 20 May 1985/Accepted 1 August 1985

\begin{abstract}
A poliovirus type I (Mahoney strain) mutant was obtained by inserting three base pairs into an infectious cDNA clone. The extra amino acid encoded by the insertion was in the amino-terminal (protein 8) portion of the P2 segment of the polyprotein. The mutant virus makes small plaques on HeLa and monkey kidney (CV-1) cells at all temperatures. It lost the ability to mediate the selective inhibition of host cell translation which ordinarily occurs in the first few hours after infection. As an apparent consequence, the mutant synthesizes far less protein than does wild-type virus. In mutant-infected CV-1 cells enough protein was produced to permit a normal course of RNA replication, but the yield of progeny virus was very low. In mutant-infected HeLa cells there was a premature cessation of both cellular and viral protein synthesis followed by a premature halt of viral RNA synthesis. This nonspecific translational inhibition was distinguishable from wild-type-mediated inhibition and did not appear to be part of an interferon or heat shock response. Because the mutant is recessive, our results imply that (at least in HeLa cells) wild-type poliovirus not only actively inhibits translation of cellular mRNAs, but also avoids early inhibition of its own protein synthesis. Cleavage of the cap-binding complex protein $\mathbf{P 2 2 0}$, which has been associated with the selective inhibition of capped mRNA translation, did not occur in mutant-infected cells. This result supports the hypothesis that cleavage of P220 plays an important role in normal poliovirus-mediated translational inhibition.
\end{abstract}

It has long been recognized that infection of cells with poliovirus results in a selective inhibition of host cell protein synthesis (for a review, see reference 2). Translation of cellular mRNA steadily declines as virus-specific translation increases; by 2 to $3 \mathrm{~h}$ after infection viral RNA, which unlike most other translated eucaryotic RNAs lacks a $5^{\prime} \mathrm{m}^{7} \mathrm{Gp}$ $\operatorname{ppN}(\mathrm{m})$ cap structure $(8,28)$, is translated almost exclusively. Presumably, a viral product mediates this inhibition, but it has not been identified.

Results of early studies have shown that translation of cellular mRNA is blocked at the initiation step (19). More specifically, the defective initiation factor appears to be a salt-stable complex composed of a cap-binding protein (CBP) and associated proteins. This complex is thought to be crucial for the attachment of capped mRNAs to $40 \mathrm{~S}$ ribosomal subunits (for a review, see reference 37 ). Infected cell extracts do not support the translation of capped RNAs (7, 34) or their attachment to the CBP complex (16), but both activities can be restored by the addition of CBP complex from uninfected cells $(17,41)$. In vivo, the decline in host protein synthesis is preceded by specific cleavage of a 220,000-dalton protein (P220) which is part of the CBP complex (6). It has been proposed that the complex is inactivated by this cleavage (6). A viral product is thought to carry out or promote the cleavage of P220, but the known viral protease (protein $7 \mathrm{c}$ ) is probably not involved $(18,23)$.

Until recently it has been difficult to apply genetics to the study of poliovirus. Mutants have been obtained by treating infected cells with chemical mutagens (for a review, see reference 4 ), but these mutants contain lesions which are difficult to map. Moreover, it is not known that they contain only one lesion or that a particular lesion is responsible for an observed phenotype. The construction of a full-length

\footnotetext{
* Corresponding author.
}

cDNA clone of poliovirus which yields infectious virus when transfected on HeLa or monkey kidney cells (33) has made it possible to construct well-defined viral mutants. Here we show that one such mutant, which has an extra amino acid in the protein 8 region of the polyprotein, is defective in the host translational inhibition function. We found an unsuspected decline of all protein synthesis in place of the normal shift to virus-specific translation in mutant-infected HeLa cells. In addition, we found that P220 is not cleaved in cells infected by this mutant.

\section{MATERIALS AND METHODS}

DNA procedures. Plasmid pSV2-polio was obtained from V. Racaniello. Restriction endonucleases and T4 DNA ligase were purchased from New England BioLabs, Inc., Beverley, Mass.; DNA polymerase I (Klenow fragment) was purchased from Boehringer Mannheim Biochemicals, Indianapolis, Ind. These enzymes were used according to the manufacturer's instructions. The modified calcium phosphate method of transfection was used in the experiments described here (30).

Cells and virus stocks. CV-1 cells (African green monkey kidney cells) were maintained in Dulbecco modified Eagle medium (DME) supplemented with $10 \%$ fetal calf serum (Hazleton). HeLa cells were grown in suspension in the Joklik modification of minimal essential medium (MEM) supplemented with $7 \%$ horse serum (GIBCO Diagnostics, Madison, Wis.).

The wild-type virus stock used in all experiments was made by isolating a single plaque from a pSV2-polio transfection and expanding it on HeLa cells by conventional means. Mutant HF121 stocks were obtained as follows. CV-1 cells seeded in $100-\mathrm{mm}$ petri dishes were transfected with mutant DNA and incubated at $37^{\circ} \mathrm{C}$ in DME supplemented with $5 \%$ fetal calf serum for 5 to 6 days. At that time the remaining cells were scraped into the medium. These 


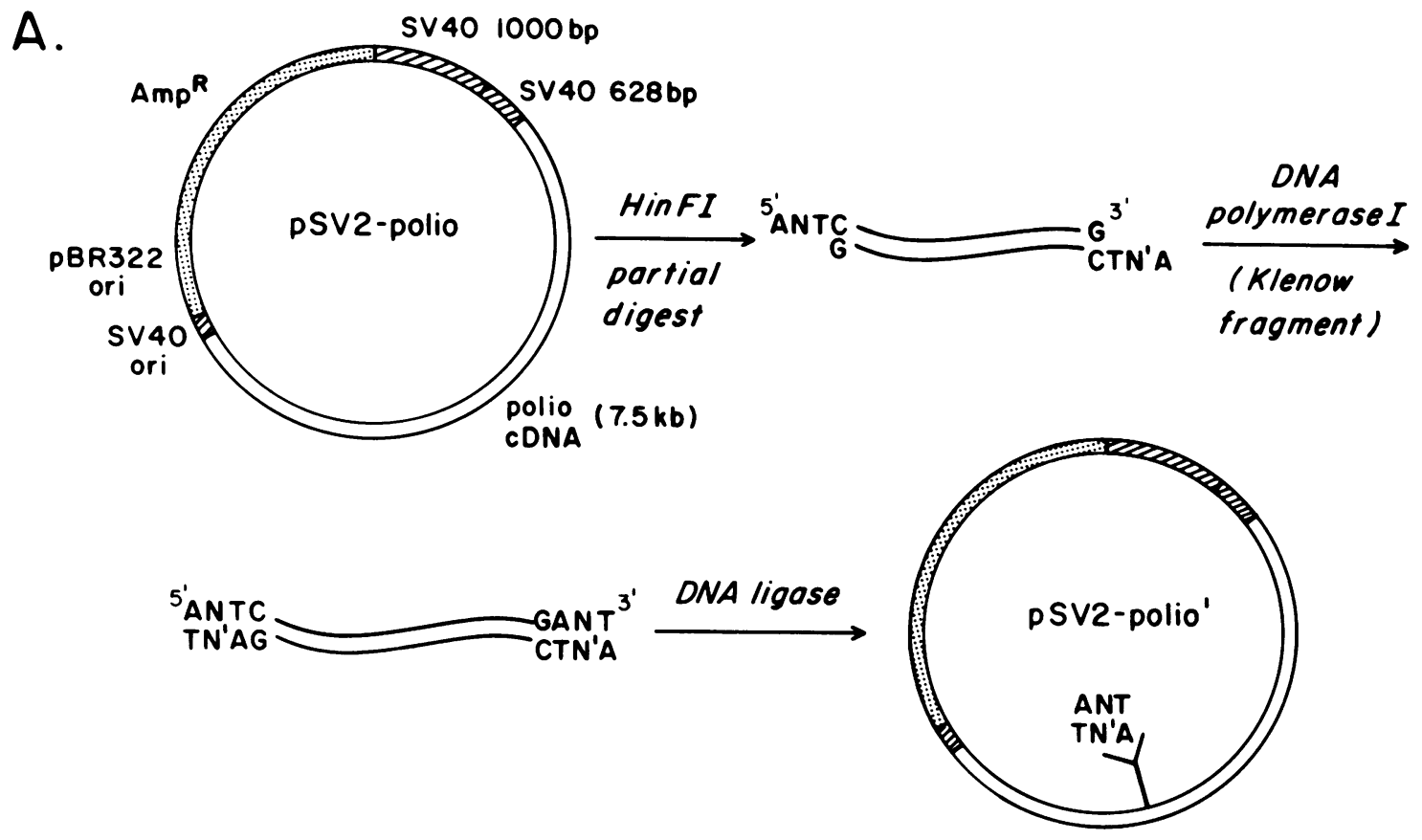

B.

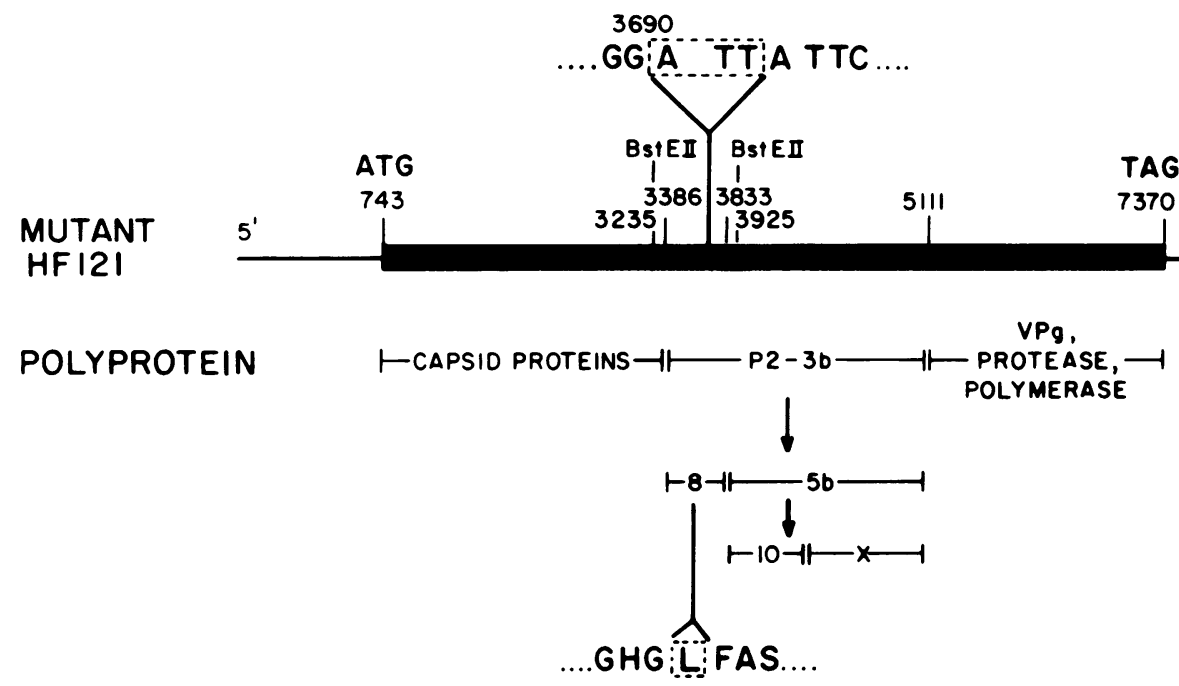

FIG. 1. (A) Strategy for generating mutants. pSV2-polio, a derivative of the mammalian expression vector pSV2 (26) which contains an infectious type I (Mahoney strain) poliovirus CDNA insert, was used in all mutagenesis experiments. The plasmid was first partially digested with the restriction endonuclease Hinfl to maximize the yield of molecules cleaved randomly at only 1 of the 43 recognition sequences in the plasmid. Linear molecules were purified by agarose gel electrophoresis. The $3^{\prime}$ ends were then filled in with DNA polymerase (Klenow fragment) and deoxynucleoside triphosphates. The DNA was recircularized with T4 DNA ligase and used to transform Escherichia coli HB101. The resulting plasmids (pSV2-polio') were then screened for the loss of single Hinfl restriction sites. Abbreviations: bp, base pairs; kb, kilobases; SV40, simian virus 40. (B) Sequence of mutant HF121. Restriction digest analysis revealed that HF121 had lost the Hinfl site at position 3690 of the poliovirus cDNA insert. The BstEII fragment between positions 3235 and 3925 was then exchanged with the equivalent wild-type fragment and shown to carry the mutant phenotype. This fragment was sequenced by the method of Maxam and Gilbert (24) and shown to be identical to the wild-type sequence $(14,32)$ except for the expected insertion. The mutant contains an extra leucine in P2-3b, and its cleavage product protein 8 as shown.

transfection stocks, which contained virus from many infectious centers, were frozen and thawed three times and then passaged once on fresh CV-1 cells. In this passage the cells were scraped into a small volume at $12 \mathrm{~h}$ postinfection and frozen and thawed three times. This procedure yielded virus stocks which were relatively free of wild-type variants and which had a sufficient titer with which to perform experiments.
Virus infections. For CV-1 infections, $60-\mathrm{mm}$ petri dishes containing $3 \times 10^{5}$ to $5 \times 10^{5}$ cells were used, except in one experiment, in which 100 -mm petri dishes containing $1.5 \times$ $10^{6}$ cells were used. The dishes were washed once, and virus was added at the appropriate multiplicity of infection (MOI) in $200 \mu \mathrm{l}$ of DME (or $400 \mu \mathrm{l}$ for $100-\mathrm{mm}$ dishes). The virus was uniformly distributed over each plate, and the cells were incubated at $37^{\circ} \mathrm{C}$ for $30 \mathrm{~min}$ to allow the virus to adsorb; 

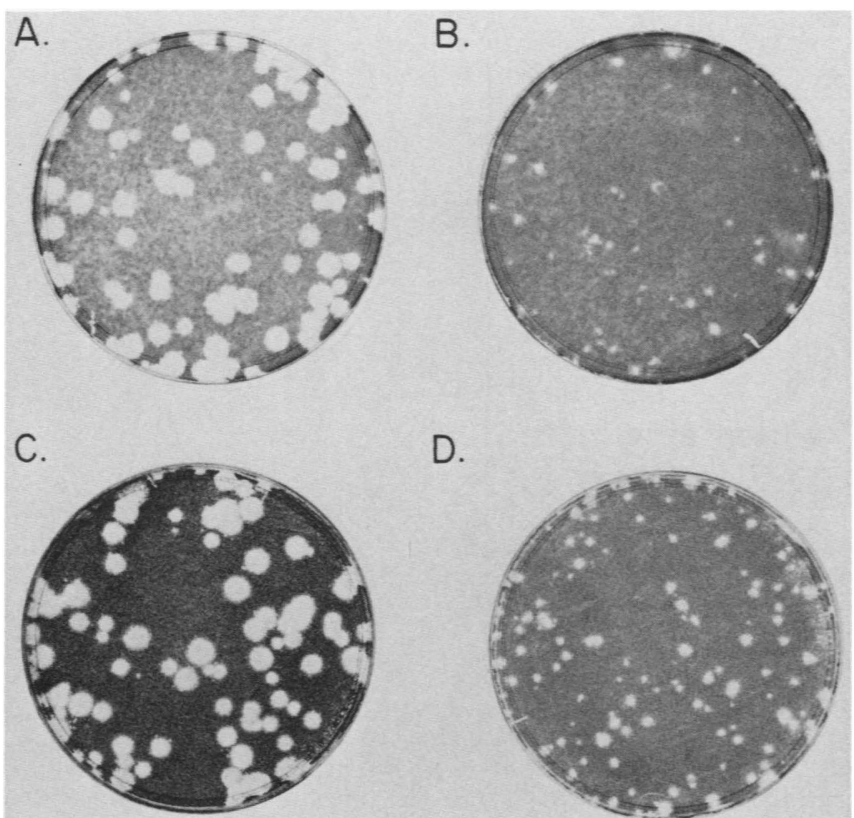

D.

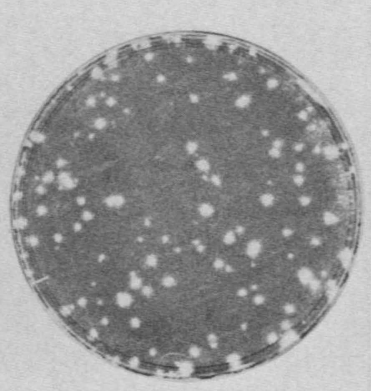

FIG. 2. Phenotype of mutant HF121. Wild-type and mutant virus stocks were prepared as described in the text. Mutant phenotype was defined by a plaque assay with monolayer CV-1 cells or HeLa cells plated from suspension shortly before inoculation. The plates were inoculated with wild-type or mutant virus and incubated at $37^{\circ} \mathrm{C}$ for approximately 40 and $65 \mathrm{~h}$, respectively, and then stained. (A) Wild-type on CV-1 monolayer; (B) mutant on CV-1 monolayer; (C) wild-type on HeLa monolayer; (D) mutant on HeLa monolayer.

during this incubation the plates were shaken periodically to facilitate adsorption. DME supplemented with $5 \%$ fetal calf serum was then added $(1.5 \mathrm{ml}$, or $2.5 \mathrm{ml}$ for $100-\mathrm{mm}$ dishes $)$, and the dishes were placed at $37^{\circ} \mathrm{C}$ for the duration of the experiment.

For HeLa infections, cells were collected by centrifugation and washed once. The cells were then suspended in as small a volume as possible of MEM containing virus (usually no more than 50 to $100 \mu \mathrm{l}$ per $3 \times 10^{6}$ cells). The virus was allowed to adsorb for $30 \mathrm{~min}$ at room temperature; during this time the tubes were shaken periodically to facilitate adsorption. The cells were then diluted in MEM supplemented with $5 \%$ fetal calf serum and $10 \mathrm{mM} \mathrm{N}-2$ hydroxyethylpiperazine- $N^{\prime}$-2-ethanesulfonic acid (pH 7.2) to a concentration of $3 \times 10^{6}$ per $\mathrm{ml}$ and stirred with a small magnetic bar in a $37^{\circ} \mathrm{C}$ water bath.

In both CV-1 and HeLa experiments in which production of progeny virus was measured, the cells were washed after adsorption and then medium was added.

Measurement of viral RNA synthesis. Actinomycin D (5 $\mu \mathrm{g} / \mathrm{ml}$ ), a gift from Merck Sharp \& Dohme, West Point, Pa., was added to cells at $15 \mathrm{~min}$ postinfection, and $\left[{ }^{14} \mathrm{C}\right]$ uridine $(0.5 \mu \mathrm{Ci} / \mathrm{ml})$, purchased from New England Nuclear Corp., Boston, Mass. ( $>350 \mathrm{mCi} / \mathrm{mmol})$, was added at $2 \mathrm{~h}$ postinfection. At appropriate times duplicate dishes of CV-1 cells were placed on ice. The medium was replaced with cold $5 \%$ trichloroacetic acid (TCA), into which the cells were scraped. In other experiments, duplicate $100-\mu$ l fractions of HeLa cells $\left(3 \times 10^{5}\right.$ cells) were added directly to $1 \mathrm{ml}$ of cold 5\% TCA. The precipitates were collected on Millipore filters, which were dissolved in Bray Solution (New England Nuclear) and counted. Poliovirus RNA synthesis was measured as TCA-precipitable counts in the presence of actinomycin D. Incorporation in actinomycin D-treated mock-infected cells was subtracted as background.

Cell extracts and electrophoretic analysis. Petri dishes containing $\mathrm{CV}-1$ cells were first washed in phosphatebuffered saline (PBS). The cells were then scraped into PBS, collected by centrifugation, and lysed in phospholysis buffer (1\% Triton $\mathrm{X}-100,0.5 \%$ sodium deoxycholate, $0.1 \%$ sodium dodecyl sulfate [SDS], $1 \mathrm{mM}$ phenylmethylsulfonyl fluoride in PBS) at a concentration of $10^{7}$ cells per ml. HeLa cells were washed twice in PBS and then lysed in phospholysis buffer at the same concentration. Chromatin was removed by centrifugation in a microfuge, and the supernatants were frozen.

SDS-polyacrylamide gel electrophoresis was performed essentially by the method of Laemmli (15), except that in some cases lower ratios of monomer to cross-linker were used in the separating gels. Gels were stained with Coomassie blue, fluorographed, dried, and autoradiographed at $-70^{\circ} \mathrm{C}$. Immunological detection of specific proteins was performed by transferring the resolved proteins to nitrocellulose by electroelution and probing with antisera essentially as described previously (42). In these experiments antigenantibody complexes were detected with ${ }^{125}$ I-labeled protein A (New England Nuclear).

Antisera. A polyclonal antiserum against protein $\mathrm{X}$ was obtained by immunizing rabbits with partially purified protein X preparations from poliovirus-infected HeLa cells ( $P$. Zabel and D. Baltimore, unpublished data). The polyclonal antiserum against cellular protein P220 has been described previously (17).

\section{RESULTS}

Construction and mapping of small-plaque mutant HF121. Racaniello and Baltimore (33) have inserted the full-length poliovirus type I cDNA into a derivative of the mammalian expression vector pSV2-gpt (26; Fig. 1A). This plasmid yields far more infectious centers on transfection than the original pBR322 derivative (P. Sarnow and D. Baltimore, unpublished data). We obtained from this clone (designated pSV2-polio) a series of single-codon insertion mutants. The mutagenesis scheme involved random linearization of the plasmid with restriction enzymes which generate three-base overhangs, filling in with DNA polymerase, and reclosing with DNA ligase (Fig. 1A). By assaying for the loss of restriction sites, we were able to map these mutants $(H$. Bernstein and D. Baltimore, unpublished data). One mutant contained an extra amino acid in the amino terminal (protein 8) region of the $P 2$ segment of the poliovirus polyprotein (Fig. 1B). When this mutant (designated HF121) was transfected onto HeLa or CV-1 cells and infectious centers were scored by plaque assay, virtually all the plaques were minute relative to the wild type. Virus stocks prepared from cells transfected with HF121 also yielded minute plaques on these and other strains of human and monkey kidney cells (Fig. 2). Whereas wild-type plaques were easily scored after $36 \mathrm{~h}$, mutant plaques were clearly visible only after $60 \mathrm{~h}$; even at this time the plaques were often still pinpoint in size. To examine whether the amino acid inserted in the protein 8 region was responsible for the phenotype of the mutant, rather than an accidental second alteration in the DNA, we exchanged the BstEII fragment of HF121 which contained the insertion (Fig. 1B) with the equivalent fragment of wild-type DNA. Only those clones which contain the altered Bst EII fragment gave rise to the mutant phenotype. In addition, the only sequence difference found between mu- 


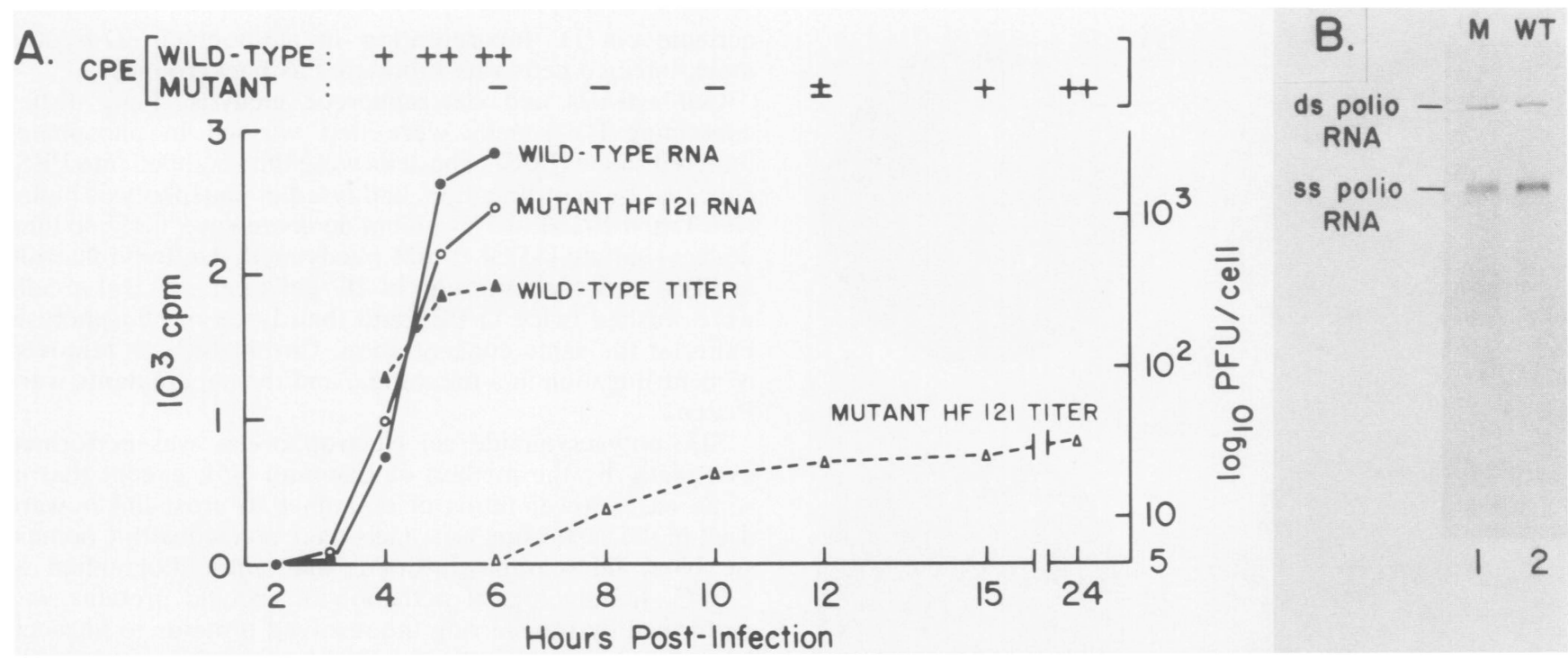

FIG. 3. Time course of RNA synthesis, progeny virus production, and appearance of cytopathic effect (CPE) in mutant- and wild-type-infected CV-1 cells. (A) CV-1 cells were infected at an MOI of 5 . Wild-type $(\bullet)$ or mutant $(O)$ RNA synthesis was measured as $\left[{ }^{14} \mathrm{C}\right]$ uridine incorporation into TCA-precipitable material in the presence of actinomycin D. Wild-type $(\Delta)$ or mutant $(\Delta)$ progeny virus production was measured as the titer of recovered virus. Cells were placed on ice at various times postinfection and scraped into the medium. After three freeze-thaw cycles titers of these stocks were determined by plaque assay. Cytopathic effect was scored as follows: -, little or no detectable rounding up of cells; + , cells clearly elongated or partially rounded up; ++ , cells ready to detach from substrate, floating in suspension, or lysed. (B) CV-1 cells were infected and treated as described above for panel A. Total cytoplasmic RNA was purified from cells harvested at $5 \mathrm{~h}$ postinfection and analyzed by electrophoresis essentially as described previously (9). RNA from approximately $10^{6}$ cells was loaded in each track. Agarose gels were stained with ethidium bromide, dried, and autoradiographed at $-70^{\circ} \mathrm{C}$. Lane 1 , mutant (M) RNA; lane 2, wild-type (WT) RNA. Abbreviations: ds, double stranded; ss, single stranded.

tant and wild-type cDNA was the three-base-pair insertion at the expected site (the sequence is shown in Fig. 1B).

Growth of HF121 in a single cycle of infection. To obtain an approximate idea of the nature of the defect in HF121, we first examined the ability of the mutant to produce infectious progeny virus in a single cycle of infection. In wild-typeinfected cells, virion assembly begins at about $3 \mathrm{~h}$ postinfection and lasts until 5 to $6 \mathrm{~h}$ postinfection. By the time normal virus production ceased, mutant-infected CV-1 cells had accumulated 50 - to 100 -fold fewer plaque-forming particles (Fig. 3A); the discrepancy was at least as great in HeLa cells (data not shown). The number of SDS-stable $150 \mathrm{~S}$ virion particles produced was also reduced to approximately the same extent (data not shown). Hence the small-plaque phenotype of HF121 was at least partially due to a low yield of progeny virus. Between 6 and $24 \mathrm{~h}$ the titer slowly increased in CV-1 cells (Fig. 3A).

We also examined the ability of HF121 to induce the dramatic morphological changes in adherent cells (the cytopathic effect) which normally precede cell death (for a review, see reference 1 ). Most wild-type-infected CV-1 cells began to pull away from the tissue culture dish by $4 \mathrm{~h}$ postinfection; between 5 and $6 \mathrm{~h}$ postinfection all of the cells rounded up and detached (Fig. 3A). At $6 \mathrm{~h}$ postinfection, however, HF121-infected CV-1 cells showed no signs of pulling away from the substrate. Cytopathic effect developed gradually (Fig. 3A) but much more heterogeneously than in a population of wild-type-infected cells. This heterogeneity in the development of the cytopathic effect may partially explain the observation that HF121 plaques are often ragged and ill defined. The small-plaque phenotype of the mutant thus can be explained by both the dramatic reduction in virus production and the prolongation of each cycle of infection.

RNA synthesis in mutant-infected cells. To further characterize the HF121 defect, we examined the ability of the mutant to replicate its genome. In CV-1 cells, HF121 synthesized RNA at the same rate and in the same quantity as wild-type virus (Fig. 3A). Moreover, the ratio of full-length, single-stranded RNA to double-stranded RNA which accumulated during the course of infection was the same as that seen during infection with wild-type virus (Fig. 3B). In HeLa cells, by contrast, mutant RNA synthesis began normally but tapered off at about $3.5 \mathrm{~h}$ postinfection and reached an early plateau. As a result the mutant made less than $20 \%$ as much RNA as wild-type virus (Fig. 4A). Furthermore, HF121-infected HeLa cells accumulated excess doublestranded RNA (Fig. 4B). This phenomenon was most evident at about $3 \mathrm{~h}$ postinfection, when double-stranded RNA was far more abundant in mutant than in wild-type-infected cells (Fig. 4B, lanes 1 and 2). Results of these experiments indicate that the physiology of the mutant is host cell dependent and suggest that the defect involves virus-host interactions.

Apparent revertants of HF121 obtained after passage on CV-1 cells also had wild-type growth properties on HeLa cells; such variants obtained after passage on HeLa cells also behaved like wild-type virus on CV-1 cells (data not shown). Because HF121 contains a single amino acid insertion, these variants very likely were produced by second-site suppressor mutations. The observation that suppression of the mutation in one cell type also suppresses the mutation in the other cell type implies that the lesion probably does not cause multiple defects in protein structure which account for the host-dependent behavior of the mutant.

Translation of host mRNA and viral RNA in mutantinfected cells. Under the conditions used in this study, wild-type poliovirus almost completely inhibits host cell translation in $\mathrm{CV}-1$ cells by $3 \mathrm{~h}$ postinfection. When whole cell extracts of cells pulse-labeled at this time with $\left[{ }^{35}\right.$ S $]$ methionine were analyzed by SDS-polyacrylamide gel 


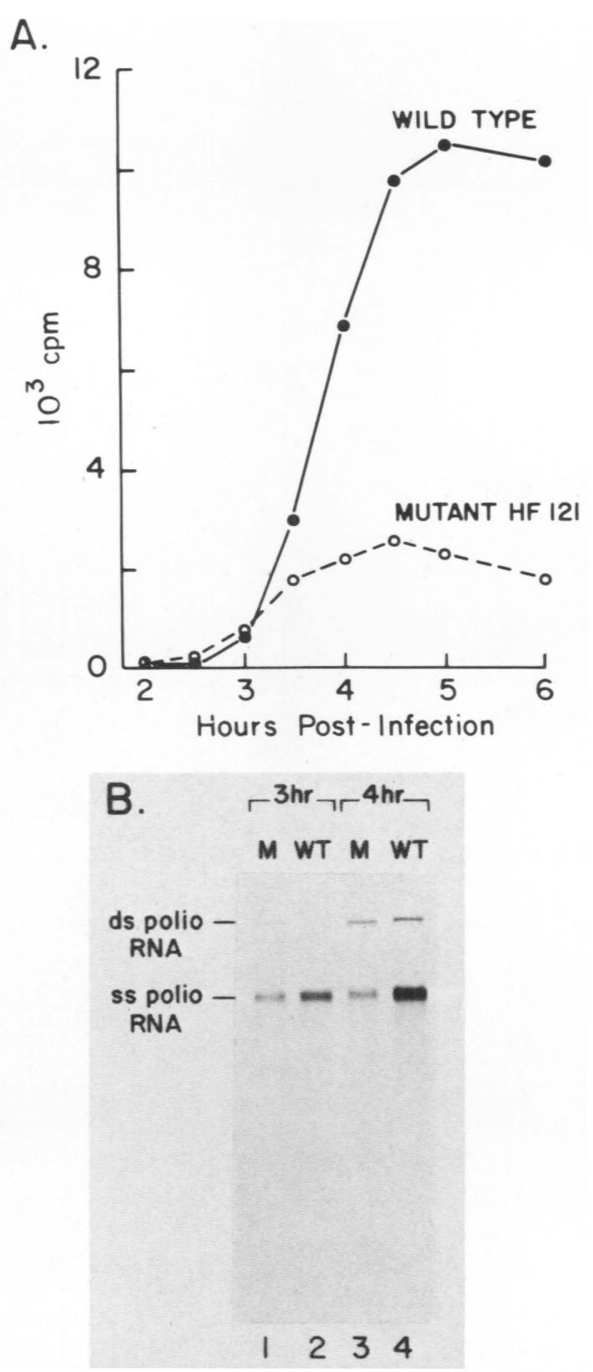

FIG. 4. Time course of RNA synthesis in mutant- and wild-typeinfected HeLa cells. (A) HeLa cells were infected at an MOI of 5. Wild-type $(\bullet)$ or mutant $(O)$ RNA synthesis was measured as $\left[{ }^{14} \mathrm{C}\right]$ uridine incorporation into TCA-precipitable material in the presence of actinomycin D. (B) HeLa cells were infected and treated as described above for panel A. Total cytoplasmic RNA was purified from cells harvested at $3 \mathrm{~h}$ (lanes 1 and 2 ) or $4 \mathrm{~h}$ (lanes 3 and 4 ) postinfection. RNA purification and agarose gel electrophoresis were as described in the legend to Fig. 3B. RNA from approximately $1.5 \times 10^{6}$ cells was loaded in lanes 1 through 3 ; one-third as much was loaded in lane 4. Lanes 1 and 3, mutant (M) RNA; lanes 2 and 4, wild-type (WT) RNA. Abbreviations: ds, double stranded; ss, single stranded.

electrophoresis, the only labeled proteins were virus specific (Fig. 5A, lane 7). By contrast, only host cell proteins were labeled in $\left.{ }^{35} \mathrm{~S}\right]$ methionine pulse-labeled extracts of mutantinfected cells (Fig. 5A, lane 6). Analysis of the electrophoretically fractionated proteins with antibody probes revealed that a detectable, but greatly reduced, amount of virusspecific protein was synthesized at this time (Fig. 5B, lane $3)$. Thus, HF121 appears to have a defect in the function which inhibits host cell translation. Little viral protein can be made in cells infected by this mutant, presumably because the viral RNA molecules must compete with a large excess of cellular mRNA for attachment to ribosomes. At 4 and $5 \mathrm{~h}$ postinfection, most of the protein that was synthesized was still host cell specific (Fig. 5A, lanes 9 and 12). As the number of HF121 RNA molecules increased with replication, however, the amount of virus-specific translation also increased; in the later $\left[{ }^{35} \mathrm{~S}\right]$ methionine pulse-labeled extracts, poliovirus proteins $1 \mathrm{~b}$ and 2 were clearly labeled (Fig. $5 \mathrm{~A}$, lanes $9,12,15$, and 17). The other viral proteins were also synthesized (Fig. 5B) but were not visible in the background of cellular protein synthesis. Even at these later times, though, the amount of viral protein which was synthesized was only a small fraction of that produced in wild-type-infected cells. Synthesis of virus-specific proteins was never predominant, as it was during wild-type infection.

After the shift from host mRNA translation to viral RNA translation occurred in wild-type-infected CV-1 cells, virusspecific proteins were made continuously until about $5 \mathrm{~h}$ postinfection (Fig. 5A, lanes 7, 10, and 13). Although infected cells exhibit morphological and biochemical alterations which become increasingly dramatic, it is not clear why translation declines late in infection (40). Also, by $5 \mathrm{~h}$ postinfection, inhibition of protein synthesis was clearly observable in HF121-infected cells, although it was much less marked than in wild-type-infected cells. By 7 to $8 \mathrm{~h}$ postinfection the rate of translation declined to less than $20 \%$ of the level seen in control cells (Fig. 5A, lanes 15 and 17). There was apparently no specificity involved in this inhibition; what viral translation was occurring was inhibited to the same degree as cellular translation.

In HeLa cells, as in CV-1 cells, the mutant did not effect a shift from host protein synthesis to virus-specific synthesis (Fig. 6). This shift was evident at $2 \mathrm{~h}$ postinfection and was complete by $3 \mathrm{~h}$ in a wild-type infection. In mutant-infected cells, however, there was a global inhibition of protein synthesis which began at $2 \mathrm{~h}$ and became very marked by 4 h postinfection (Fig. 6, lanes 5,8 , and 11 ), during a period when virus-specific translation was at its height in wild-typeinfected cells. Presumably because the copy number of mutant RNA molecules is relatively low when the inhibition occurs, virus-specific proteins were detectable only with antibody probes (data not shown). As in CV-1 cells, translation of both cellular RNAs and poliovirus RNA was similarly affected by the mutant-induced inhibition, but, whereas global inhibition of protein synthesis became evident after RNA synthesis was complete in CV-1 cells, it occurred in HeLa cells at a time when the linear phase of RNA synthesis was just beginning. This early cessation of protein synthesis paralleled and may explain the observed decline in RNA synthesis. Experiments with inhibitors of protein synthesis such as puromycin have shown that inhibition of translation leads to a gradual shutdown in viral RNA synthesis (35).

We can further distinguish the nonspecific mutant-induced inhibition of translation in both CV-1 and HeLa cells from normal poliovirus-induced host inhibition. It has been shown that $1 \mathrm{mM}$ guanidine hydrochloride specifically blocks viral replication but permits synthesis of viral protein and does not affect cellular metabolism (for a review, see reference 2). When this inhibitor was added at $3 \mathrm{~h}$ postinfection to mutant-infected CV-1 cells, at a time when wild-typemediated translational inhibition was complete, the mutant did not induce a translational decline (Fig. 7A). When guanidine was added at the time of infection of HeLa cells, wild-type virus was still able to depress host cell translation relatively well, but the mutant did not induce translational inhibition (Fig. 7B). Apparently, as suggested by results of previous studies (31), input wild-type RNA molecules that are prevented from undergoing replication by guanidine are 


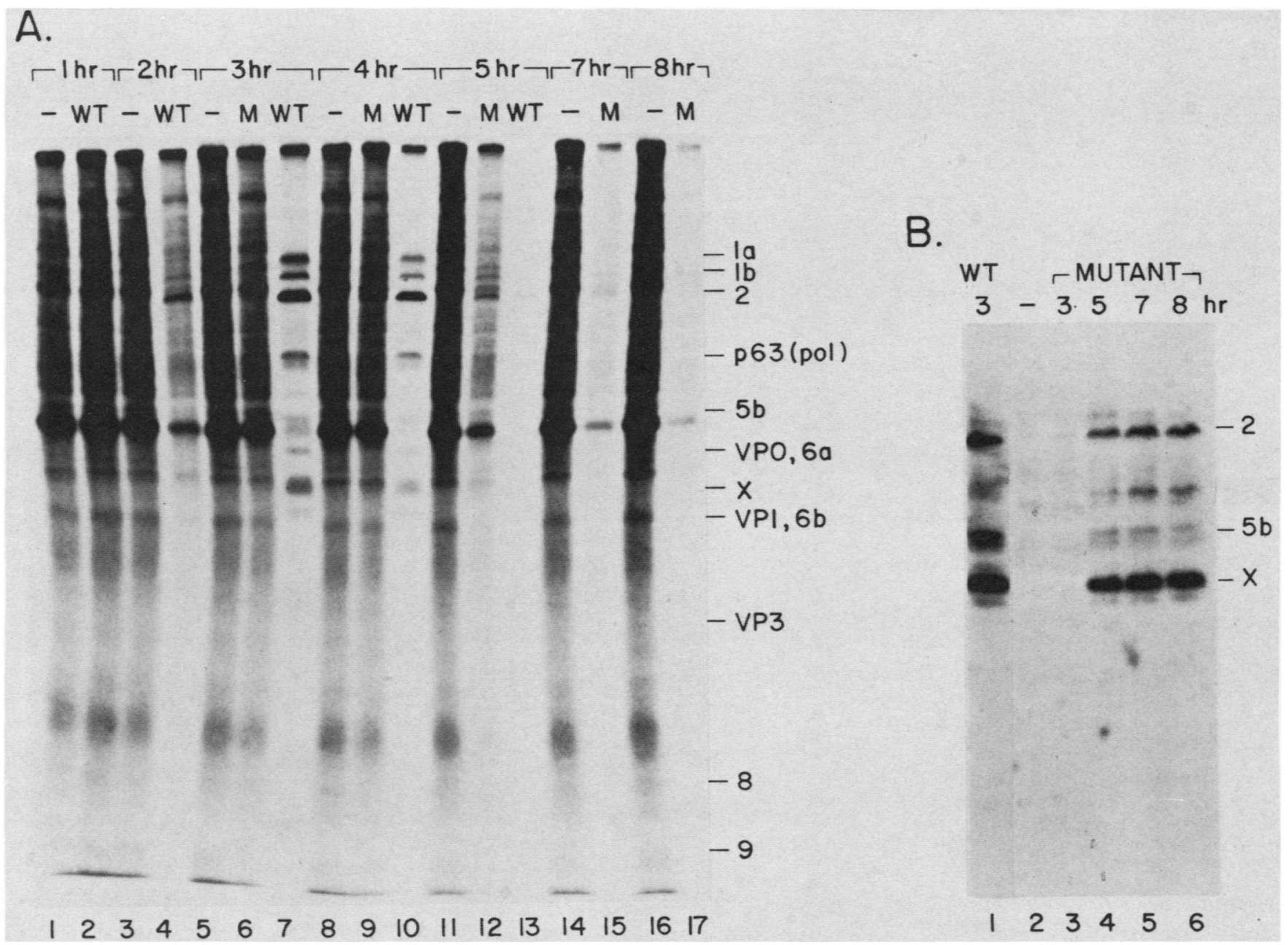

FIG. 5. Pattern of protein synthesis in mock-, mutant- (M), and wild-type (WT)-infected CV-1 cells at various times after infection. (A) CV-1 cells were infected at an MOI of 10 . At various times after infection, medium was removed from appropriate dishes and replaced with methionine-free DME containing 5\% dialyzed fetal calf serum. $\left[{ }^{35} \mathrm{~S}\right]$ methionine $(>800 \mathrm{Ci} / \mathrm{mmol}$; New England Nuclear) was added to a final concentration of $50 \mu \mathrm{Ci} / \mathrm{ml}$. Cells were incubated at $37^{\circ} \mathrm{C}$ for $10 \mathrm{~min}$ and then placed immediately on ice. Cell extracts were made as described in the text. A portion $(25 \mu \mathrm{l})$ of each extract was analyzed by electrophoresis through a $15 \%$ SDS-polyacrylamide-0.09\% $N, N^{\prime}$ methylenebisacrylamide gel. Lanes $1,3,5,8,11,14$, and 16 , mock-infected extracts (-); lanes 6, 9, 12, 15, and 17, mutant-infected extracts (M); lanes 2, 4, 7, 10, and 13, wild-type-infected extracts (WT). (B) Portions (25 $\mu \mathrm{l})$ of CV-1 extracts shown in panel A were resolved on a $15 \%$ SDS-polyacrylamide- $0.09 \% N, N^{\prime}$-methylenebisacrylamide gel, and the resolved proteins were then transferred to nitrocellulose. The filter was probed with a polyclonal antiserum against poliovirus protein X. (As shown above, this serum also contains some activity against poliovirus proteins that contain p63 sequences, including p63, 1b, and 2 . Lane 1 , wild-type-infected extract (WT) at $3 \mathrm{~h}$ postinfection; lane 2 , mock-infected extract at $8 \mathrm{~h}$ postinfection; lanes 3 through 6 , mutant-infected extracts at 3, 5, 7, and $8 \mathrm{~h}$ postinfection.

able to direct synthesis of sufficient amounts of protein to cause an inhibition of host cell translation. By contrast, the mutant-induced global inhibition of protein synthesis must require extensive accumulation of viral products and cannot be produced by input RNA.

The nonspecific mutant-induced translational inhibition does not appear to be identical to previously identified cellular responses to viral infection. Because the inhibition occurred even when actinomycin $\mathrm{D}$ was added prior to or at the time of HF121 infection (data not shown), it did not involve the production of new cellular transcripts. Results of this experiment rule out the possibility that it was the result of a cellular response to interferon treatment or a consequence of interferon induction. Actinomycin D blocks the effects of interferon; these include sharp elevation of the level of a double-stranded, RNA-dependent protein kinase which is thought to inhibit protein synthesis by phos- phorylating the $\alpha$-subunit of eucaryotic initiation factor 2 $(13,20)$. No new major cellular proteins were synthesized after the onset of the mutant-induced inhibition (Fig. 5A and 6 ); in this respect HF121-infected cells did not appear to undergo the typical stress response induced by exposure to elevated temperatures or toxic substances (for a review, see reference 36 ).

Fate of the CBP complex protein P220 in HF121-infected cells. As described above, poliovirus-induced translational inhibition has been correlated with characteristic cleavage of the CBP complex protein P220. We examined whether this protein was cleaved in mutant-infected cells by probing electrophoretically fractionated proteins from those cells with an antiserum raised against $\mathrm{P} 220$. As has been shown previously $(17,18)$, the specific cleavage products of $\mathrm{P} 220$, which migrate at $\sim 120,000$ daltons, give a stronger signal in this type of analysis than does the uncleaved protein. The 


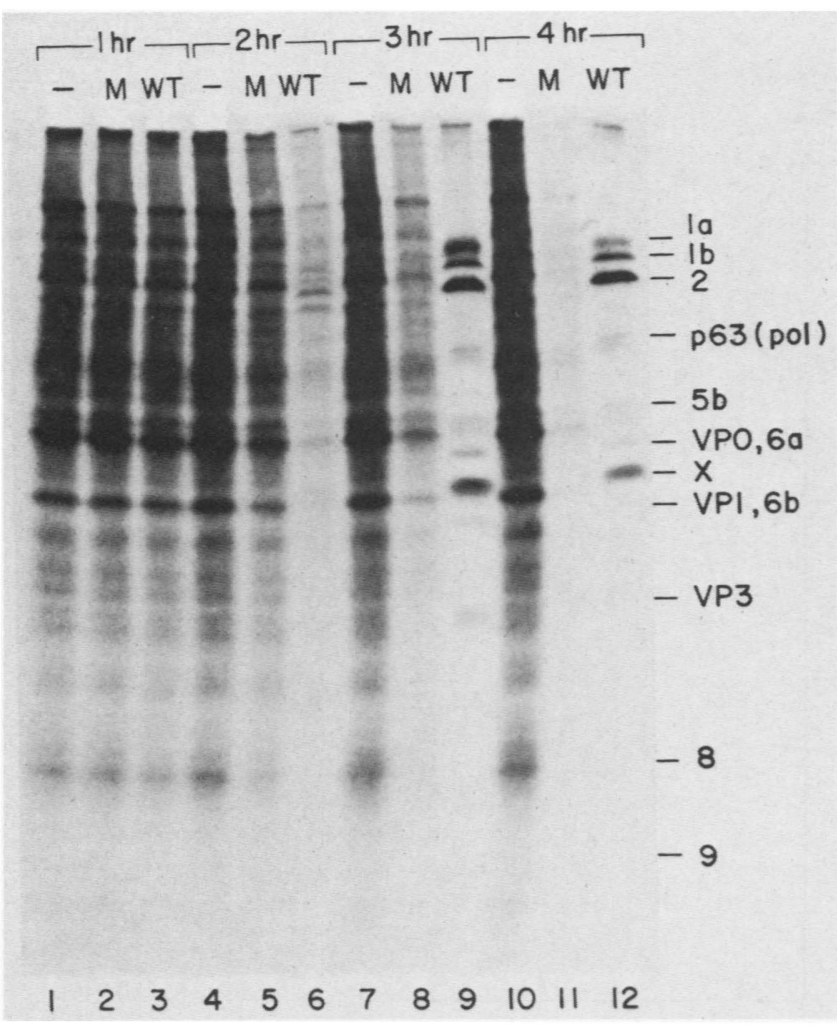

FIG. 6. Pattern of protein synthesis in mock-, mutant-. and wild-type-infected HeLa cells at $1-4$ hours after infection. HeLa cells were infected at an MOI of 10 . At $1,2,3$, and $4 \mathrm{~h}$ after infection, $1.5 \times 10^{6}$ cells from each culture were collected by centrifugation and suspended in methionine-free DME containing $5 \%$ dialyzed fetal calf serum. $\left[{ }^{35} \mathrm{~S}\right]$ methionine was added to a final concentration of $50 \mu \mathrm{Ci} / \mathrm{ml}$. Cells were stirred at $37^{\circ} \mathrm{C}$ for $10 \mathrm{~min}$ and then placed immediately on ice. Cell extracts were made as described in the text. A portion $(30 \mu \mathrm{l})$ of each extract was analyzed by electrophoresis through a $15 \%$ SDS-polyacrylamide- $0.09 \% N . N^{\prime}$ methylenebisacrylamide gel. Lanes $1,4,7$, and 10, mock-infected extracts $(-)$; lanes $2,5,8$, and 11 , mutant-infected extracts $(M)$ : lanes $3,6,9$, and 12 , wild-type-infected extracts (WT).

signal discrepancy appears to be particularly large with CV-1 cell extracts. As a result, the most reliable indication of the fate of P220 in these cells is the level of cleavage products. In wild-type-infected CV-1 cells, P220 cleavage products were evident by $2 \mathrm{~h}$ postinfection (Fig. 8A, lane 4). In mutantinfected CV-1 cells, by contrast, significant levels of cleavage products were not evident; the small amount present only in Fig. 8A, lane 7 ( $5 \mathrm{~h}$ postinfection) is often found in mock-infected cells (Fig. 8A, lane 2; N. Sonenberg, unpublished data). In the mutant-infected cells intact P220 was clearly detectable over the entire course of infection (Fig. $8 \mathrm{~A}$, lanes 6 through 8 ), despite the marked decline in protein synthesis. In wild-type-infected HeLa cells, P220 was cleaved even more rapidly than in $\mathrm{CV}-1$ cells; cleavage products were evident by $1 \mathrm{~h}$ postinfection, and by $2 \mathrm{~h}$ more extensive cleavage had occurred (Fig. 8B, lanes 4 and 5). Yet in mutant-infected HeLa cells, even at $4 \mathrm{~h}$ postinfection, when translation was inhibited by $>80 \%$, no cleavage products were evident (Fig. 8B, lanes 7 through 9). In the mutant-infected cells intact P220 was clearly present throughout the course of infection. To be sure that the absence of P220 cleavage was not due to a problem with the mutant infections, we monitored translation rates in both
CV-1 and HeLa experiments and found that they followed previously observed kinetics. These observations further support the hypothesis that poliovirus-mediated selective suppression of capped mRNA translation involves cleavage, and presumably therefore inactivation, of P220.

\section{DISCUSSION}

We used a cDNA copy of poliovirus type I to create a mutation in the protein 8 region of the viral genome. The resulting small-plaque mutant failed to selectively inhibit the translation of cellular mRNA in monkey kidney $(\mathrm{CV}-1)$ and human (HeLa) cells. As an apparent consequence, only a small fraction of the normal amount of viral protein was synthesized. In certain respects the behavior of the mutant was host cell dependent. It produced a full yield of RNA in CV-1 cells, but in HeLa cells there was a premature inhibition of all protein synthesis followed by an inhibition of viral RNA synthesis. In both cell types, infection with the mutant virus failed to elicit the cleavage of cellular protein P220, which is a component of the protein complex that facilitates the binding of the $5^{\prime}$ cap on cellular mRNAs to $40 \mathrm{~S}$ ribosomal subunits. The data imply that the protein 8 region encodes a function which either directly or indirectly causes cleavage of P220. Our experiments also provide genetic evidence in support of previous suggestions that cleavage of P220 is an integral part of the virally mediated inhibition of host cell translation.

Virus-induced inhibition of host cell protein synthesis. The lesion in HF121 is located within the coding sequence for two poliovirus proteins, protein 8 and the larger protein $3 \mathrm{~b}$. One or the other is probably responsible for mediating host translational inhibition. However, we cannot completely rule out a long-range effect on the folding or cleavage of another part of the polyprotein which could affect a distant function. At a gross level the lesion does not prevent or alter the cleavage of $\mathrm{P} 2$ from the polyprotein or any of the cleavages within P2 (Fig. 5B). Additional studies on the protein 8 region, and possibly construction of additional mutants, should help resolve this issue.

Although cleavage of P220 appears to be an important part of translational inhibition, poliovirus may not act directly on that protein. Because cleavage products which comigrate with those seen after poliovirus infection can also appear in lesser amounts in uninfected cells, it might be suspected that the virus activates a normal cellular mechanism which is responsible for the turnover of $\mathrm{P} 220$. Protein 8 contains a sequence of over 20 amino acids, however, which is strikingly similar to a portion of the known viral protease (protein 7c). A comparison of this sequence to the National Biomedical Research Foundation protein library with the program of Lipman and Pearson (22) reveals clear homology with a variety of known serine proteases. The aligned region of these proteases includes the highly conserved sequence GDSGG (27) which contains the active site serine. Curiously, a cysteine is substituted for the serine in both 8 and 7c. The insertion in mutant HF121 is located a few amino acids before the region of similarity between the two viral proteins.

Cleavage of P220 may also be only a part of the process by which poliovirus inhibits host cell translation. Other events have been observed to occur soon after infection and in the absence of viral replication. These include extensive rearrangement of the cytoskeletal framework, with which translation initiation factors (3) and ribosomes (11) are associated, and dissociation of both ribosomes and mRNA from this matrix (21). It is not clear what, if any, role these events play 
A.

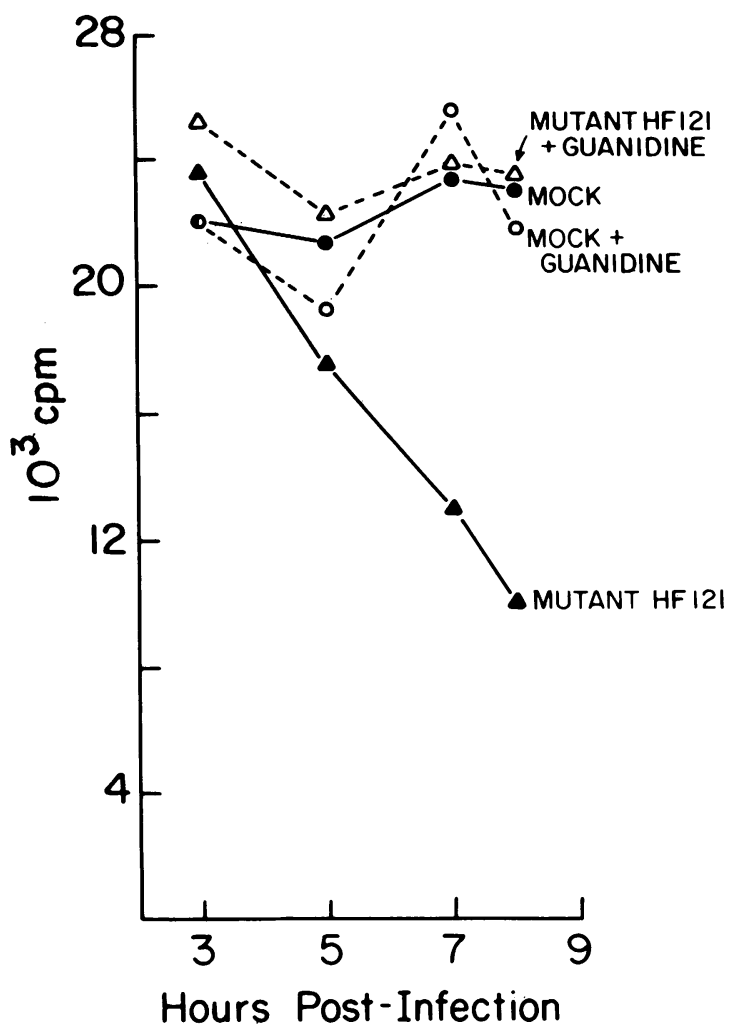

B.

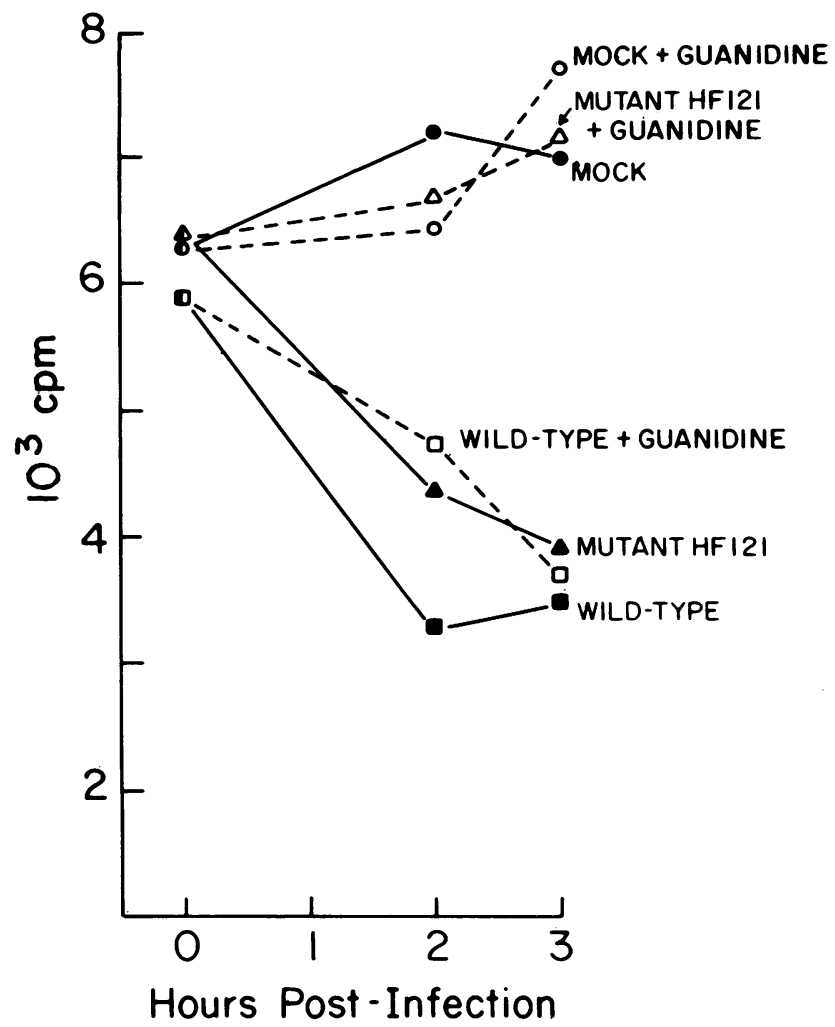

FIG. 7. Ability of mutant and wild-type virus to potentiate translational inhibition in the presence of guanidine. (A) CV-1 cells were mock infected or infected with mutant virus at an MOI of 5 . At $3 \mathrm{~h}$ postinfection, $1 \mathrm{mM}$ guanidine hydrochloride was added to half of the dishes. Then at 3, 5, 7, and $8 \mathrm{~h}$ postinfection $5 \mu \mathrm{Ci}$ of $\left.{ }^{35} \mathrm{~S}\right]$ methionine per $\mathrm{ml}$ was added to duplicate plates of both treated and untreated cells. The cells were labeled for $10 \mathrm{~min}$ at $37^{\circ} \mathrm{C}$ and then placed immediately on ice. Protein synthesis was measured as TCA-precipitable counts by harvesting the cells in the way described for RNA synthesis experiments. Symbols: $\bullet$, Mock-infected cells; $\bigcirc$, mock-infected cells and cells treated with guanidine; $\boldsymbol{\Delta}$, mutant-infected cells; $\Delta$, mutant-infected cells and cells treated with guanidine. (B) HeLa cells were infected at an MOI of 15 . After adsorption of the virus, each culture was suspended in medium and divided in half, and 1 mM guanidine hydrochloride was added to one portion. Then at $0,1,2$, and $3 \mathrm{~h}$ postinfection $200 \mu \mathrm{l}$ of cells was removed from each sample and placed in new tubes along with $5 \mu \mathrm{Ci}$ of $\left[{ }^{35} \mathrm{~S}\right]$ methionine per $\mathrm{ml}$. Pulse-labeling and measurement of protein synthesis were carried out as described above for panel A. Symbols: $\bullet$, mock-infected cells; $\bigcirc$, mock-infected cells and cells treated with guanidine; $\boldsymbol{\Delta}$, mutant-infected cells; $\Delta$, mutant-infected cells and cells treated with guanidine; $\mathbf{\square}$, wild-type-infected cells; $\square$, wild-type-infected cells and cells treated with guanidine.

in translational inhibition or how they relate to cleavage of P220.

Most other picornaviruses inhibit the translation of host cell proteins. Human rhinovirus 14 , which is highly homologous to poliovirus at the amino acid level (including in the protein 8 region) (39), also mediates the cleavage of P220 in HeLa cells (5). Unlike poliovirus, however, encephalomyocarditis (EMC) virus does not appear to inactivate any translation initiation factors (12). For this reason it has been proposed that EMC virus and poliovirus utilize different mechanisms to effect translational inhibition (12). In accord with this proposal, evidence has recently been obtained that P220 is not cleaved in EMC virus-infected cells (25). Although at the amino acid sequence level poliovirus $(14,32)$ is less related to EMC virus (29) than to human rhinovirus 14 , its capsid, protease, polymerase, and $\mathrm{X}$ proteins are clearly homologous to the corresponding EMC virus proteins. Poliovirus protein 8, however, is not homologous to its EMC counterpart, protein $\mathrm{G}$. Thus it might be imagined that the two proteins have different functions. At the very least, the assignment of the poliovirus translational inhibition function to a region of the polyprotein which has a different sequence in EMC virus is consistent with the notion that the two viruses effect translational inhibition in different ways.

Consequences of the mutation in HF121. Although the single amino acid insertion in HF121 has complex consequences for the virus, certain functions are unaffected by the mutation. These include viral RNA synthesis in monkey kidney cells and the formation of virions (in proportion to the reduction in titer) which have normal hydrodynamic properties, stability, and composition (data not shown). The other aspects of the HF121 infection cycle are best considered separately for the different host cells studied.

The small amount of viral protein made in CV-1 cells in the absence of translational inhibition is sufficient for RNA synthesis but not for extensive particle formation. Hence the virus has probably evolved the ability to selectively inhibit host cell protein synthesis primarily because a large amount of protein is required to encapsidate viral RNA molecules. Each virion is formed from 60 copies of each capsid protein but only one RNA molecule. One copy of VPg (the 5'terminal protein on the RNA) and, possibly, no more than one copy of each protein involved in replication may be sufficient to form each RNA molecule. The small-plaque 


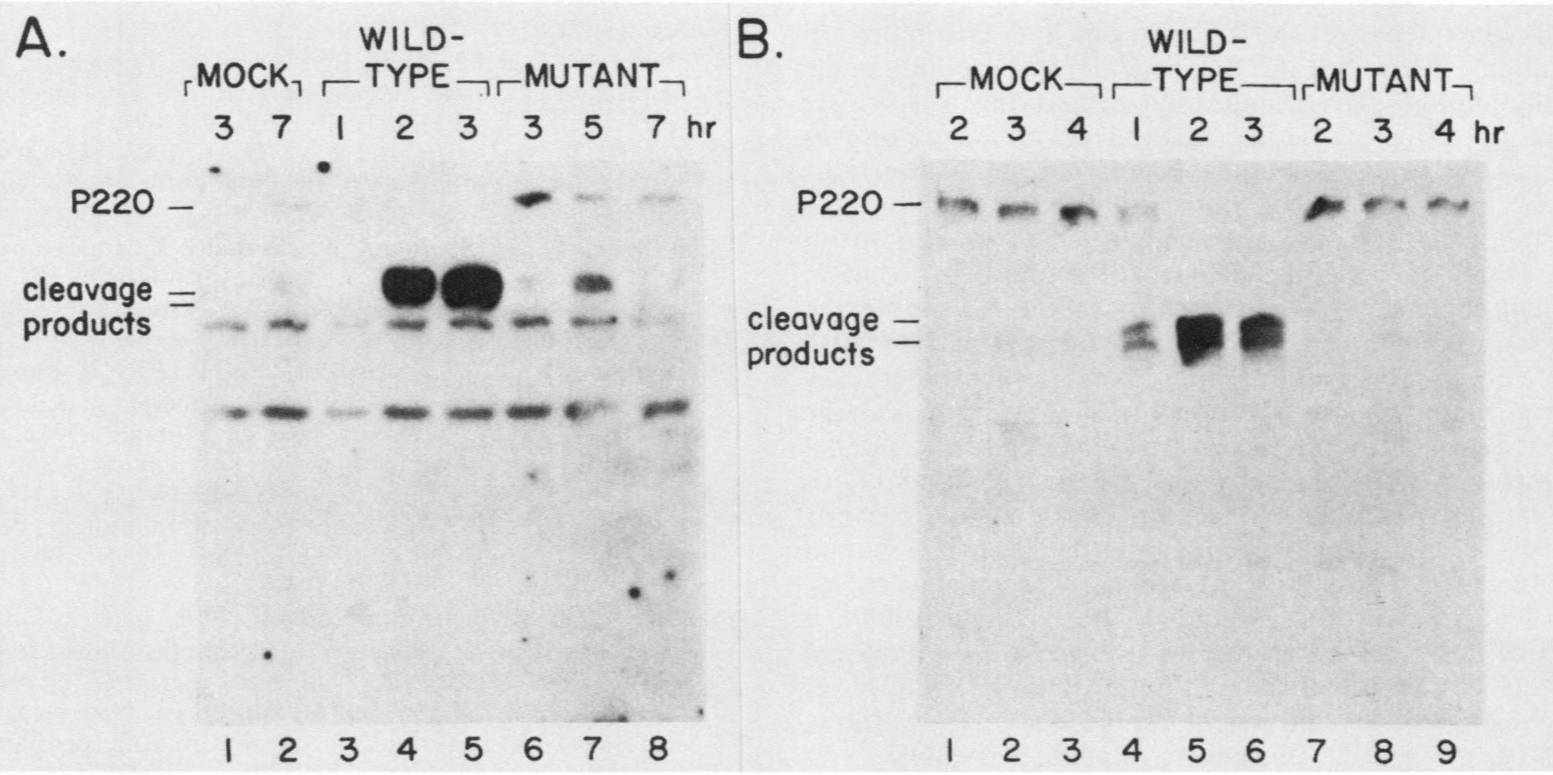

FIG. 8. Fate of P220 in mock-, mutant-, and wild-type-infected cells. (A) CV-1 cells plated on 100-mm petri dishes were infected at an MOI of 5. At various times after infection cells were placed on ice and harvested. Extracts were made as described in the text. A portion (50 $\mu$ ) of each extract was analyzed by electrophoresis on a 6.5 to $12 \%$ SDS-polyacrylamide gradient gel, and the resolved proteins were then transferred to nitrocellulose. The filters were probed with a polyclonal antiserum against P220. Lanes 1 and 2, mock-infected cells at 3 and $7 \mathrm{~h}$ postinfection; lanes 3 through 5 , wild-type-infected cells at 1.2 . and $3 \mathrm{~h}$ postinfection: lanes 6 through 8 . mutant-infected cells at 3,5 , and $7 \mathrm{~h}$ postinfection. (B) HeLa cells were infected at an MOI of 5. At various times after infection portions of each culture were removed and placed on ice. Extracts were made as described in the text. A portion $(50 \mu \mathrm{l})$ of each sample was analyzed by electrophoresis on a $6.5 \%$ SDS-polyacrylamide gel; the resolved proteins were transferred to nitrocellulose and probed with anti-P220 serum. Lanes 1 through 3. mock-infected cells at 2 to $4 \mathrm{~h}$ postinfection; lanes 4 through 6 . wild-type-infected cells at 1 to $3 \mathrm{~h}$ postinfection: lanes 7 through 9 . mutant-infected cells at 2 to $4 \mathrm{~h}$ postinfection.

phenotype of the mutant is largely explained by the low yield of progeny virus. The slow development of cytopathic effect and the delay of cell lysis may also be partly responsible, but these phenomena are probably secondary consequences of the reduction in viral protein synthesis or particle formation.

In mutant-infected CV-1 cells there is a late inhibition of all protein synthesis. This global inhibition may be the same event which normally occurs at about $5 \mathrm{~h}$ postinfection and terminates viral RNA and protein synthesis. It may be part of a cellular response to the accumulation of viral products. The discovery of a premature inhibition of all protein synthesis in mutant-infected HeLa cells, however, raises the possibility that this decline is a delayed version of an event that has no counterpart in wild-type-infected cells.

Whatever the mechanism of the mutant-induced early translational inhibition in HeLa cells, it is clearly distinguishable from wild-type-induced inhibition on four counts. First, it is prevented by treatment with guanidine, whereas normal inhibition is not. Second, it is not correlated with a cleavage of P220. Third, it inhibits viral as well as host protein synthesis and therefore does not work selectively on capped mRNAs. Fourth, it is accompanied by a premature inhibition of viral RNA synthesis and a relative increase in the accumulation of double-stranded RNA. (Excess double-stranded RNA synthesis also has been noted in cells treated with guanidine [2]). Apparently continuous, though not necessarily efficient, translation of poliovirus proteins is required for normal RNA synthesis. The global inhibition could be a normal cellular response to infection but is not obviously related to interferon or heat shock-induced responses. We are currently investigating whether this phenomenon nevertheless involves phosphorylation of eIF2. Recently, the translational decline seen in HeLa cells infected by a VA I RNA deletion mutant of adenovirus has been reported to involve phosphorylation (by an as yet undetermined kinase) of this translation factor (38).

There are two plausible explanations for the premature inhibition of translation in mutant-infected HeLa cells. The mutant may have lost a function which ordinarily blocks, or at least delays, the development of global translational decline. This could be either a second activity of the protein $8 / 3 \mathrm{~b}$ region or another aspect of the same activity that leads to P220 cleavage. Alternatively, it might be thought that the mutation in HF121 could generate a new viral function which effects an abnormal translational decline. This second possibility is unlikely because HF121 is a recessive mutant. It can be complemented in either HeLa or CV-1 cells by every other mutant tested so far. Mixed infections with the second mutant increases the titer of HF121 in a single cycle of infection by as much as 50- to 100 -fold. Additionally, HeLa cells coinfected with HF121 and wild-type virus synthesize RNA normally (H. Bernstein and D. Baltimore, manuscript in preparation). Thus the implication of these results is that, at least in HeLa cells, wild-type poliovirus not only selectively inhibits the synthesis of capped mRNAs but also has the ability to avoid the nonselective translational inhibition which occurs in HF121-infected cells.

Poliovirus mutants made by manipulating DNA. One implication from these studies is that useful poliovirus mutants, and presumably mutants of other related plus-stranded viruses, can be made by manipulating infectious cDNA. HF121, the mutant described here, is one of three defective (yet viable) poliovirus mutants of a total of 24 generated by the strategy of filling in different three-base overhang restric- 
tion enzyme cleavage sites (Bernstein and Baltimore, in preparation). These are the first well-defined mutants made by manipulating cDNA and then recovering virus after transfection. This particular method of mutagenesis was chosen partly because we suspected that small insertions would be more stable than point mutations given the high error rate of the RNA polymerase (10). Even so, variants of HF121 which have wild-type growth properties do arise. Presumably these are the product of second-site suppressor mutations. In fact, because of the tendency of HF121 to generate apparent revertants (there is no permissive growth condition under which selection for such variants can be minimized), mutant virus stocks are expanded from a pool of infectious foci. This is possible only because each infectious center obtained through expression of the cDNA clone is effectively a separate isolate of the virus. If such a mutant had been generated by conventional means, which is to say that it would have to be expanded from a single isolate, it might well have been lost due to overgrowth by apparent revertants. Other mutants have been obtained from other mutagenesis schemes and will be reported soon (P. Sarnow, K. Kirkegaard, and D. Baltimore, unpublished data).

\section{ACKNOWLEDGMENTS}

We thank Peter Sarnow and Karla Kirkegaard for continuous support and helpful suggestions during the course of this work and for comments on the manuscript. We also thank Dolores Harrison for excellent technical assistance. The anti-P220 antiserum was a gift from Isaac Edery.

This work was supported by Public Health Service grant AI22346 from the National Institute for Allergy and Infectious Diseases to D.B. and a grant from the Medical Research Council and National Cancer Institute of Canada to N.S.

\section{LITERATURE CITED}

1. Bablanian, R. 1975. Structural and functional alterations in cultured cells infected with cytocidal viruses. Prog. Med. Virol. 19:40-83.

2. Baltimore, D. 1969. The replication of picornaviruses, p. 101-176. In H. Levy (ed.), The biochemistry of picornaviruses. Marcel Dekker, Inc., New York.

3. Cervera, M., G. Dreyfuss, and S. Penman. 1981. Messenger RNA is translated when associated with the cytoskeletal framework in normal and VSV-infected HeLa cells. Cell 23:113120.

4. Cooper, P. D. 1977. Genetics of picornaviruses, p. 133-207. In H. Fraenkel-Conrat and R. R. Wagner (ed.), Comprehensive virology, vol 9. Plenum Publishing Corp., New York.

5. Etchison, D., and S. Fout. 1985. Human rhinovirus 14 infection of HeLa cells results in the proteolytic cleavage of the p220 cap-binding complex subunit and inactivates globin mRNA translation in vitro. J. Virol. 54:634-638.

6. Etchison, D., S. C. Milburn, I. Edery, N. Sonenberg, and J. W. B. Hershey. 1982. Inhibition of HeLa cell protein synthesis following poliovirus infection correlates with the proteolysis of a 220,000-dalton polypeptide associated with eukaryotic initiation factor 3 and cap binding protein complex. J. Biol Chem. 257:14806-14810.

7. Helentjaris, T., and E. Ehrenfeld. 1978. Control of protein synthesis in extracts from poliovirus-infected cells. I. mRNA discrimination by crude initiation factors. J. Virol. 26:510-521.

8. Hewlett, M. J., J. K. Rose, and D. Baltimore. 1976. 5'-Terminal structure of poliovirus polyribosomal RNA is pUp. Proc. Natl. Acad. Sci. USA 73:327-330.

9. Hewlett, M. J., S. Rosenblatt, V. Ambros, and D. Baltimore. 1977. Separation and quantitation of intracellular forms of poliovirus RNA by agarose gel electrophoresis. Biochemistry 16:2763-2767.

10. Holland, J., K. Spindler, F. Horodyski, E. Grabau, S. Nichol, and S. VandePol. 1982. Rapid evolution of RNA genomes.
Science 215:1577-1585.

11. Howe, J. G., and J. W. B. Hershey. 1984. Translation initiation factor and ribosome association with the cytoskeletal framework fraction from HeLa cells. Cell 37:85-93.

12. Jen, G., B. M. Detjen, and R. E. Thach. 1980. Shutoff of HeLa cell protein synthesis by encephalomyocarditis virus and poliovirus: a comparative study. J. Virol. 35:150-156.

13. Kimchi, A., L. Shulman, A. Schmidt, Y. Chernajovsky, A. Fradin, and M. Revel. 1979. Kinetics of the induction of three translation-regulatory enzymes by interferon. Proc. Natl. Acad. Sci. USA 76:3208-3212.

14. Kitamura, N., B. L. Semler, P. G. Rothberg, G. R. Larsen, C. J. Adler, A. J. Dorner, E. A. Emini, R. Hanecak, J. J. Lee, S. van der Werf, C. W. Anderson, and E. Wimmer. 1981. Primary structure, gene organization and polypeptide expression of poliovirus RNA. Nature (London) 291:547-553.

15. Laemmli, U. K. 1970. Cleavage of structural proteins during the assembly of the head of bacteriophage T4. Nature (London) 291:547-553

16. Lee, K. A. W., and N. Sonenberg. 1982. Inactivation of capbinding proteins accompanies the shut-off of host protein synthesis by poliovirus. Proc. Natl. Acad. Sci. USA 79:3447-3451.

17. Lee, K. A. W., I. Edery, and N. Sonenberg. 1985. Isolation and structural characterization of cap-binding proteins from poliovirus-infected HeLa cells. J. Virol. 54:515-524.

18. Lee, K. A. W., I. Edery, R. Hanecak, E. Wimmer, and N. Sonenberg. 1985. Poliovirus protease 3C (P3-7c) does not cleave P220 of the eucaryotic mRNA cap-binding protein complex. J. Virol. 55:489-493.

19. Leibowitz, R., and S. Penman. 1971. Regulation of protein synthesis in HeLa cells. III. Inhibition during poliovirus infection. J. Virol. 8:661-668.

20. Lengyel, P. 1982. Biochemistry of interferons and their actions. Annu. Rev. Biochem. 51:251-282.

21. Lenk, R., and S. Penman. 1979. The cytoskeletal framework and poliovirus metabolism. Cell 16:289-301.

22. Lipman, D. J., and W. R. Pearson. 1985. Rapid and sensitive protein similarity searches. Science 227:1435-1441.

23. Lloyd, R. E., D. Etchison, and E. Ehrenfeld. 1985. Poliovirus protease does not mediate the cleavage of the 220,000 dalton component of the cap binding protein complex. Proc. Natl. Acad. Sci. USA 82:2723-2727.

24. Maxam, A. M., and W. Gilbert. 1980. Sequencing end-labeled DNA with base-specific chemical cleavages. Methods Enzymol. 65:499-560.

25. Mosenkis, J., S. Daniels-McQueen, S. Janovec, R. Duncan, J. W. B. Hershey, J. A. Grifo, W. C. Merrick, and R. E. Thach. 1985. Shutoff of host translation by encephalomyocarditis virus infection does not involve cleavage of the eucaryotic initiation factor $4 \mathrm{~F}$ polypeptide that accompanies poliovirus infection. $\mathrm{J}$. Virol. 54:643-645.

26. Mulligan, R. C., and P. Berg. 1981. Selection for animal cells that express the Escherichia coli gene coding for xanthineguanine phosphoribosyltransferase. Proc. Natl. Acad. Sci. USA 78:2072-2076.

27. Neurath, H., K. A. Walsh, and W. P. Winter. 1967. Evolution of structure and function of proteases. Science 158:1638-1644.

28. Nomoto, A., Y. F. Lee, and E. Wimmer. 1976. The $5^{\prime}$ end of poliovirus mRNA is not capped with $\mathrm{m}^{7} \mathrm{G}\left(5^{\prime}\right) \mathrm{pppNp}$. Proc. Natl. Acad. Sci. USA 73:375-380.

29. Palmenberg, A. C., E. M. Kirby, M. R. Janda, N. L. Drake, G. M. Duke, K. F. Potratz, and M. S. Collett. 1984. The nucleotide and deduced amino acid sequences of the encephalomyocarditis viral polyprotein coding region. Nucleic Acids Res. 12:2969-2985

30. Parker, B. A., and G. R. Stark. 1979. Regulation of simian virus 40 transcription: sensitive analysis of the RNA species present early in infections by virus or viral DNA. J. Virol. 31:360-369.

31. Penman, S., and D. Summers. 1965. Effects on host cell metabolism following synchronous infection with poliovirus. Virology 27:614-620.

32. Racaniello, V. R., and D. Baltimore. 1981. Molecular cloning of poliovirus cDNA and determination of the complete nucleotide 
sequence of the viral genome. Proc. Natl. Acad. Sci. USA 78:4887-4891.

33. Racaniello, V. R., and D. Baltimore. 1981. Cloned poliovirus complementary DNA is infectious in mammalian cells. Science 214:916-919.

34. Rose, J. K., H. Trachsel, K. Leong, and D. Baltimore. 1978. Inhibition of translation by poliovirus: inactivation of a specific factor. Proc. Natl. Acad. Sci. USA 75:2732-2736.

35. Scharf, M. D., M. M. Thoren, N. F. McElvain, and L. Levintow. 1963. Interruption of poliovirus RNA synthesis by $p$ fluorophenylalanine and puromycin. Biochem. Biophys. Res. Commun. 10:127-132.

36. Schlesinger, M. J., M. Ashburner, and A. Tissières (ed.). 1982. Heat shock: from bacteria to man. Cold Spring Harbor Laboratory, Cold Spring Harbor, N.Y.

37. Shatkin, A. 1985 . mRNA cap binding proteins: essential factors for initiating translation. Cell 40:223-224.

38. Siekierka, J., T. M. Mariano, P. A. Reichel, and M. B. Mathews. 1985. Translational control by adenovirus: lack of virus- associated RNA I during adenovirus infection results in phosphorylation of initiation factor eIF-2 and inhibition of protein synthesis. Proc. Natl. Acad. Sci. USA 82:1959-1963.

39. Stanway, G., P. J. Hughes, R. C. Mountford, P. D. Minor, and J. W. Almond. 1984. The complete nucleotide sequence of a common cold virus: human rhinovirus 14. Nucleic Acids Res. 12:7859-7875.

40. Summers, D. F., J. V. Maizel, Jr., and J. E. Darnell, Jr. 1967. The decrease in size and synthetic activity of poliovirus polysomes late in the infectious cycle. Virology 31:427-435.

41. Tahara, S. M., M. A. Morgan, and A. J. Shatkin. 1981. Two forms of purified $m^{7} G$-cap binding protein with different effects on capped mRNA translation in extracts of uninfected and poliovirus-infected HeLa cells. J. Biol. Chem. 256:76917694.

42. Towbin, H., T. Staehelin, and J. Gordon. 1979. Electrophoretic transfer of proteins from polyacrylamide gels to nitrocellulose sheets: procedure and some applications. Proc. Natl. Acad. Sci. USA 76:4350-4354. 